\title{
Financial Behavior of Working Women in Investment Decision-Making
}

\author{
Nadia Asandimitra, Tony Seno Aji, Achmad Kautsar \\ Faculty of Economics, Universitas Negeri Surabaya, East Java, Indonesia \\ nadiaharyono@unesa.ac.id, tonyseno@unesa.ac.id,achmadkautsar@unesa.ac.id
}

\begin{abstract}
The purpose of this study is to measure the level of financial literacy of working women, to describe assets allocation, as well as the time and profit in investment. This research paper is a qualitative study using the descriptive method. Noting the purpose, it is suitable if the qualitative approach was implemented. The respondents are working women with most of them have been married, 16-22 years old on average, have a bachelor degree, and work in the government sector with the majority of the income is more than 4.000.000 rupiahs. Those respondents' characteristics will influence their choice in doing investment because it is associated with the tolerance of risks. The first form of behavior and preference of investment done by working women is that majority of them have thought about investment plan and most of the respondents think that everyone can get profitable investment if they do financial planning and saving/investment. The second form of behavior is that the majority of respondents are more interested in property investment. The third form of behavior motivating working women in doing investment is themselves, like retirement planning and family security reason. Based on the study, it shows that working women have high financial literacy which is indicated by their discipline in doing the investment of their excess money, thus they have control over their finances and believe to get investment profit they should do financial planning.
\end{abstract}

Keywords: Financial Behavior, Working Women, Investment Decision-Making, Financial Literacy, Assets Allocation.

\section{Introduction}

According to the data of Regional Office of Manpower (East Java Province in Figures, 2017), there is the increasing number of labor in East Java, noting that in 2012, there were 524.381 male job seekers, then it declined by about 116.061 into 408.320 . While for females, in 2012, there were 209.840 of female job seekers which rose as much as 145.014 into 435.854 . From those 2012 data, female worker placement is greater than a male worker. It is $67.96 \%$ of the female worker had a job while it is only $52.88 \%$ of the male worker had a job. The greater number of female job seekers absorbed indicates the more job vacancy for women. The increasing number of female workers needs to be balanced with the quality of workforce education. This is also indicated by the direct proportional between the increasing number of working women and the level of women's education due to the quality of working women becomes one of the requirements that need to be considered. Many companies began to apply the minimum requirement, bachelor graduates, in their requirement which can be seen from the higher number of university graduates absorption comparing to High School graduates. Based on the national workforce survey, the unemployment rate of university graduates in 2014 is only 43.987 lower than the unemployment rate of high school graduates reaching 204.982 (East Java Province in Figures, 2017). According to the Central Statistics Agency of East Java, the number of women who completed bachelor degrees increased to $5.55 \%$ in 2011 from $5.36 \%$ in 2010.

The more working women also support the increase of family income because the family income which formerly only comes from the husband is added by income from the wife. Women who work will contribute to the increase of family income, that is, it can encourage the family to invest (Mincer \& Polachek, 1974). With women's role becoming increasingly important in families and communities, it is important to examine behavior in working women. Investment in a broad sense consists of two main parts, namely investment in the form of real assets and investment in the form of securities or financial assets. Real assets are tangible assets such as gold, diamonds, silver, art and real estate. Financial assets are securities that are a claim of real assets controlled by an entity (Hartono, 2003). The investment decision-making process is a process that describes how an investor decides the type of investment, how much investment, and when the investment will be made. Decision-making, in general, is a complex phenomenon encompassing all aspects of life, involving various dimensions, and the process of choosing from the myriad options available. Decisionmaking theory is based on the concept of satisfaction, that is, the utility is the amount of pleasure or relative 
satisfaction achieved. With this amount, individuals enable to determine the increase or decrease of utility to increase satisfaction. Having this concept, each action is to maximize the amount of utility to achieve satisfaction.

Hence, investment decision making is made rationally to maximize its utility. At first, the investors in making investing not only estimate the prospects of investment instrument, but also the psychological factors, which contribute to determining the investment. Even, various parties stated that the psychological factor of the investor has a significant role in investing. Investment decisions are influenced by investors' biases and prejudice that will affect assets' prices. The existence of these psychological factors gives an impact on the investment and its result achieved. Thereby, an investment analysis using psychology and financial science is known by Behavioral Finance. Behavioral Finance has emerged as a new discipline that seeks to understand the psychological and financial interaction to develop models and theories to have a deeper and better understanding of the investment decision-making process and their impact on financial markets. Financial Behavior departs from classical finance theory due to it recognizes that investors will be influenced by psychological and emotional factors (Mittal, 2010). Shefrin (2000) defines behavioral finance as a study of how psychological phenomena influencing their financial behavior. The behavior of stock players, which Shefrin (2000) stated, is about practitioners' behavior. Baker \& Nofsinger (2010) defines the behavioral finance is a study examining how humans behave in a financial setting.

Especially, learning how psychology influences the decisions of finance, corporate and financial markets. Thus, the financial theory explains how individuals should make financial decisions while behavioral finance shows how individuals make a financial decision. Hinz, McCarthy, \& Turner (1997); Byrnes, Miller, \& Schafer (1999); and Bernasek \& Shwiff (2001) examining investment behavior found that women were more risk-averse than men, while Sunden \& Surette (1998) claimed that gender and marital status were significantly associated for asset allocation. Hibbert, Lawrence, \& Prakash (2008) disclose that risks related to gender, age, income, wealth, marital status, race/ethnicity, and the number of children under 18 in the family. Olsen \& Cox (2001) found that women are more risk-averse than men when faced with social and technological dangers, even when both have the same expertise and experience. Recent studies have reported that women are more at risk-averse and more at choosing less-risky pension assets comparing to men (Yuh \& Hanna, 1997); (Sung, 1997); (Bajtelsmit \& VanDerhei, 1997); (Selvi, 2012); (Bahl, 2012); (Indrawan, 2014); dan (Retno, 2014). Since stocks and personal businesses are usually viewed as a low-risk investment, it is expected that women will choose less frequent types of assets than men. It is also expected that women will invest a greater proportion of their portfolios in low-risk investments.

The lower risk assets, in this case, are real assets. Other research Indrawan (2014) dan Retno (2014) found that age, educational level, status, number of dependent family members, ownership of house and land affecting investment decision of working women. Indicators of investment capacity which can be measured based on investor wealth, investment objective, attitude to risk, and investment period has been proven to be a primary determinant of choice among investment asset classes (Butler \& Domian, 1991). Based on the formulation of the problem, the specific objectives of this study are first to measure the financial literacy level of working women; Second, the description of asset allocation, time and the desired level of profit in investing in working women; Third, testing internal factors such as education level, status, sex, length of work and number of members covered and factors of home ownership, land ownership and access to credit that affect investment decisions of working women. The advantages of this study are compared to previous research: First, this study is more comprehensive and in-depth in exploring investment behavior of working women starting from measuring the level of financial literacy to the meaning behind the investment decisions taken; Second, this research is rarely found in the field of financial management, because it is related to personal finance; and Third, in the end this research will bring up the conceptual model of investment decisions for working women

\section{Literature Review}

Theory of Planned Behavior: Theory of Planned Behavior (TPB) was postulated by Icek Ajzen in 1985 as the extension from Theory of Reasoned Action. There are three variables of the Theory of Planned Behavior. 
Attitude: Attitude refers to a general feeling expressing a person's favor or against an object that drives his response, both in the form of positive and negative responses (Ajzen, 1985). Attitude is a general evaluation created by the human against themselves, others, objects, or issues (Azwar, 2000). According to Notoatmodjo (1997), attitude is a reaction or a person's response that still close to a stimulus or object. Also, according to Purwanto (1998) attitude is views or feelings that are accompanied by the tendency to act according to the attitude of the object. Allport (1954) used a two-component approach; attitude is defined as a mental and neural stage of readiness, organized through experience, pursuing a directional and dynamic influence on the individual response to all related objects and situations. To make a clearer understanding, researchers will use one of the empirical indicators of attitude, that is, knowledge. In the previous study, Chen \& Volpe (1998) explained that education in financial management has a significant relationship in making important investment decisions. Chen \& Volpe (1998) concluded that the influence of individual financial knowledge levels influences them in the decision-making process. Knowledge is like a stimulus for people who do not know. Similar to investment products, investment products are seen as knowledge. People who already understand about investment products will, at least, know the benefits and the risks. This, after knowing investment products, women will be interested try to invest in those products.

Subjective Norms: According to Kreitner \& Kinicki (2001), subjective norms are interpreted as an acceptance of social pressure to show a specific behavior. Ajzen \& Fishbein (1977) explained that subjective norms are individual perceptions related to most of the people who are important to him expecting individuals to do or not to do certain behaviors, those who are important to him then be used as a reference or benchmark for directing behavior. Based on Mowen (1995), subjective norms value is something that is believed by the consumers that they should do based on people's assumptions. In other words, subjective norms include strong influences from the promoter group into the formulation of a behavior. According to Dharmmesta (1998), subjective norms are social factors that show the perceived social pressure to perform or not to perform actions/behaviors. Ajzen (1991) explained that subjective norms are perceived social pressure to perform or not to perform the behavior. The subjective norm refers to the influence of family, colleagues and the social environment. Suppose in everyday life we hang out with friends who smoke. Because of many friends who smoke, then we will also participate in smoking. The environment can affect one's behavior. For investment products themselves, the intended environment is related to the social environment. For example, when you meet your neighbors who invest in one investment product and then he tells the profits he gets, then it will encourage us to invest in the mentioned product.

Perceived Behavior Control: The perceived behavior control is perceived ease or difficulty in performing the behavior (Ajzen, 1991). The perceived behavior control is usually thought to consist of difficulty and controlling factors (Ajzen \& Fishbein, 2000). The perceived behavior control is a function of a control belief and easy access to the factor of the belief control, a control is the presence or absence of resources and opportunities required to perform certain behaviors, whereas an easy access to the control factor is an assessment of one's interest in resources to obtain the expected outcomes of behavior (Chang, 1998). Control is very important than attitudes and norms, it is said so because it can directly affect behavior. For example is money, in this case, a student who has the funds can just buy the available investment products, they can also find out the new investment products then he/she will be dare to invest. The next thing, if the three things are met and there is an interest, then we just need to wait for the decision to invest. In conducting research on the behavior of an investor, several aspects are needed to be learned that is about investment planning Bahl (2012); Jisha \& GoMathi (2017), how the asset allocation Bahl (2012); Warren, Stevens, \& McConkey (1990); Rajarajan (2000), the reasons of doing the investment Bahl (2012); Jain (2014); and its resistance to a risk (Eckel \& Grossman, 2002); (Gneezy, Leonard, \& List, 2009). 
Figure 1: Theory of Planned Behaviour

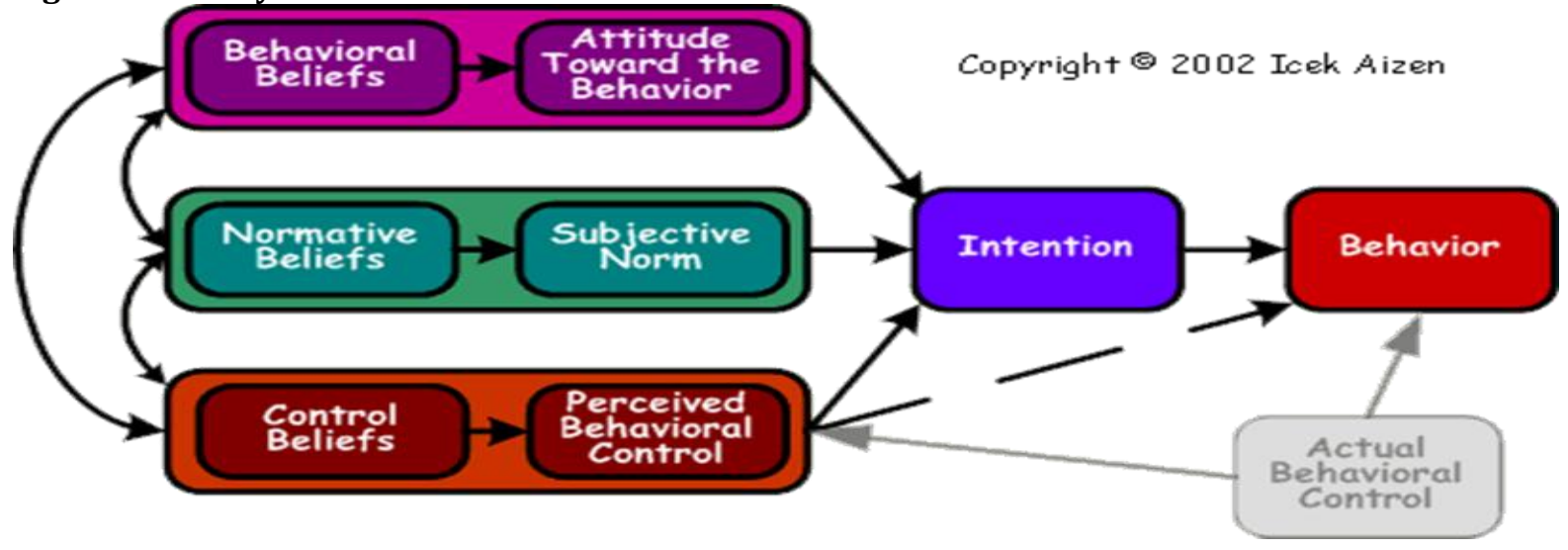

Investment: According to Tandelilin (2010), investment is a commitment to several other funds or resources being made at the moment, aimed at gaining some profit in the future. According to Hartono, (2003), investment is a delay of now consumption to be used in an efficient production over a certain period. According to Sunariyah (2003), investment is a capital investment for one or more owned assets and usually a long-term asset in the hope of gaining profit in the future. Sources of funds for investment can come from owned current assets, loans from other parties, or savings. Investors who reduce their current consumption will have the possibility of excess funds to save. According to Heidi Hartman, family income is the birth base of the labor division by sex, because it is based on the notion that women are not expected to generate an economic contribution to households, and that women's work priority is on domestic responsibility. In reality, few families resemble that myth. The funds derived from the savings, if it is invested, it will provide hope of increased consumption ability of the investor in the future, which is obtained from improving the welfare of investors (Tandelilin, 2010).

More specifically, Tandelilin (2010) outlines some of the reasons for people who do investment, among others, as follows:

- To get a better life in the future, a wise man will think about how to improve his or her life from time to time or at least try to maintain his income level in order not to diminish in the future.

- To reduce the inflation pressures, by investing in the ownership of a corporation or other object, a person may avoid the risk of impairment of property or property due to the influence of inflation.

- To encourage saving on taxes. Some countries in the world do many policies that encourage the growth of investment in society through the provision of tax facilities to people who invest in certain areas.

Investment in the broad sense consists of two main parts, namely: investment in the form of real assets and investment in the form of bonds or securities (financial assets). Real assets are tangible assets such as gold, diamonds, silver, art and real estate. Financial assets are bonds that are claims of real assets controlled by an entity (Hartono, 2003).

Investment Decision: Investment decisions are an important factor in the financial function, that the value of a company is solely determined by the investment decisions. The statement implies that investment decision is important because to achieve the company's goal of maximizing wealth (wealth), the shareholders will only be generated through corporate investment activities (Hidayat, 2010). As already mentioned, the advantage (return) derived from investment activities are generally capital gains and dividends. The earned dividend is determined by the company's ability to make a profit. Meanwhile, capital gains are influenced by fluctuations in stock prices. The ability of companies to earn profits is influenced by micro and macro factors, which in turn will affect the fluctuation of stock prices, and will raise investment risk (Rahadjeng, 2011).

Financial behavior has a significant role in making investment decisions. Decision-making is a process of selecting the best alternative from several alternatives available under the influence of complex situations. 
Investment decision-making will be greatly influenced by the obtained information as well as investor knowledge of the investment, whereas each investor has a different level of ability and knowledge. Investment decision-making is influenced by (1) the extent to which investment decisions can maximize wealth, and (2) behavioral motivation, investment decisions based on investor psychological aspects. Investment decision makers do not always behave consistently with assumptions made by perceptions and understanding of the received information (Christanti \& Mahastanti, 2011); (Jahanzeb, Muneer, \& Ur-Rehman, 2012); (Peteros \& Maleyeff, 2013).

The Concept of Work and Family Income: Talk about work is usually associated with productive work and unproductive work. Productive work is usually associated with men's work in making money while unproductive work is usually associated with house chores that do not directly generate money. Some theories argue that house chores can be analyzed by using a framework of self-analysis as productive work. Although women also work to earn a living, many women's jobs are not considered equal to productive work done by men even by women themselves. Efforts to improve this condition can only be done by looking back at the definition of work in different ways because women are more involved in unpaid work, house chores, and family businesses, etc. By assigning a value to women's work equivalently to men's work, even though women's jobs often do not result in the form of money, because the value of a work is not assessed in the form of money only. Therefore, there is no reason to consider women's work unequally to men's work just because women's jobs do not make money. There are other issues that also need to be considered when we talk about working women this is related to how society and women themselves in assessing the income of working women.

\section{Research Methodology}

This study is a descriptive study, which attempts at solving the problem by illustrating the prevailing problems. It is based on the consideration that researchers wanted to understand, examine in depth, and present, in this paper, about investment decisions by working women and problems found as well as the way to face it to create good and optimum investment decision-making. Based on this reason, this study used a qualitative approach. No matter how big the income of working women is, they are still regarded as an additional livelihood, which is closely related to the stereotype that men as the head of the family and the main breadwinner. The population of this study is women lecturers and the academic staff of the Economics Faculty. A random sampling technique was used in this study. A random sampling technique was used in this study.

The research sampling technique used in this study is saturated sampling. Saturated sampling technique is a sampling technique if all parts of the population are used as research samples. Data analysis is the process of finding and organizing interviews and records obtained in the field and other materials that have been collected to formulate the results of what has been found. Relevant to the type of research that is qualitative research with the descriptive method, the analysis technique used is qualitative analysis techniques. The data that has been collected in the form of words from various sources are analyzed intensively. The data analysis was done using a qualitative data analysis technique by giving an intensive analysis of data obtained using words. Some steps used to analyze the data are mentioned below:

Data Collection: In a qualitative study, the data was collected from field/empirical evidence to compose theory from the data.

Data Classification: The first classification of data includes whether the women working invest or not. Then, it would be analyzed the composition of investment for these following categories.

- $\quad$ Stock investment

- Investment in financial instruments

- Insurance investment

- $\quad$ Risk-Free Investment (Savings \& Deposits)

Data Presentation: Data presentation was intended to facilitate the researchers to see the statistical description of the proportion of investment made by working women. 
Conclusion: After the data presentation step, the initial conclusion could be drawn. The conclusion made was also reached during the research. From the beginning until the data collection process, the researchers attempted to do analysis and find the meaning of what has been collected.

\section{Results and Discussion}

This study took a sample of female academicians of the Faculty of Economics Universitas Negeri Surabaya which consists of employees, lecturers, students, alumni, and 'dharmawanita' (an organization for the wives of Indonesian civil servants) as many as 100 people. The following will be described the research data expressed in the tabulation form.

Table 1: Demographic Characteristics of Respondents

\begin{tabular}{llll}
\hline No & Criteria & & Percentage \\
\hline 1. & Age & $16-22$ & $2.4 \%$ \\
& & $23-30$ & $48.8 \%$ \\
& & $>30$ & $48.8 \%$ \\
2. & Education level & Primary & 0 \\
& & Middle & 0 \\
& & High & $2.4 \%$ \\
& & Associate degree/bachelor degree & $50 \%$ \\
& & Master degree & $38.1 \%$ \\
3. & Marital status & Doctoral degree & $9.5 \%$ \\
& & Single & $48.8 \%$ \\
4. & Occupation & Married & $51.2 \%$ \\
& & Working in Government Sector & $57.1 \%$ \\
5. & Income & Working in the Private Sector & $47.6 \%$ \\
& & $500,000-2,000,000$ & $3.6 \%$ \\
& & $2,000,000-4,000,000$ & $45.2 \%$ \\
\end{tabular}

Table 2 below shows that the majority of working women have considered about investment plan. Notwithstanding that, the investment plan is only in their mind and has not been got further execution; it becomes the starting point to develop the next investment plan. The result can be seen from the third statement, which has a higher average score compared to others, that is $3,22$.

Table 2: Investment Planning Status of Working Women

\begin{tabular}{|c|c|c|c|c|c|c|c|}
\hline No & Statement & $\begin{array}{l}\text { Score } \\
1(\mathrm{STS})\end{array}$ & $2(\mathrm{TS})$ & $3(S)$ & $4(S S)$ & Total & Average \\
\hline 1 & $\begin{array}{l}\text { I have an investment plan } \\
\text { that has been developed. }\end{array}$ & $4 \%$ & $16 \%$ & $51 \%$ & $29 \%$ & $100 \%$ & 3.04 \\
\hline 2 & $\begin{array}{l}\text { I have problems in } \\
\text { developing } \\
\text { investment. }\end{array}$ & $9 \%$ & $43 \%$ & $37 \%$ & $11 \%$ & $100 \%$ & 2.49 \\
\hline 3 & $\begin{array}{l}\text { I am thinking of } \\
\text { developing an investment } \\
\text { plan. }\end{array}$ & $3 \%$ & $4 \%$ & $62 \%$ & $32 \%$ & $100 \%$ & 3.22 \\
\hline 4 & $\begin{array}{l}\text { I am not thinking at all } \\
\text { about the investment plan }\end{array}$ & $73 \%$ & $21 \%$ & $7 \%$ & $0 \%$ & $100 \%$ & 1.34 \\
\hline
\end{tabular}

Table 3 shows the perception of working women about the precise time for doing investment planning. There are some possibilities of time used, they are: in the beginning time of joining company/business, as early as 
possible in the workplace, and in the middle of having a job. The result shows that the majority of respondents think that the best time to do investment is at the beginning of joining an organization or company. It can be seen from the second statement, which has a higher average score compared to others, that is 3,07 . According to some respondents, an earlier period of working is the time when people attempt to understand and learn about the job description, they are often more confronted with two things, understanding the job description and do the job, or unable to understand the job description and make investment from their salary obtained from early months of working (by getting that monthly salary, it will boost financial independence).

Table 3: Working Women Perception of the Right Time to Do Investment Planning

\begin{tabular}{|c|c|c|c|c|c|c|c|}
\hline No & Statement & $\begin{array}{l}\text { Score } \\
1 \text { (STS) }\end{array}$ & 2(TS) & $3(S)$ & $4(S S)$ & Total & Average \\
\hline 1 & $\begin{array}{l}\text { The best time to start } \\
\text { planning investment is in } \\
\text { the beginning when } \\
\text { someone joins a company. }\end{array}$ & $14 \%$ & $29 \%$ & $41 \%$ & $16 \%$ & $100 \%$ & 2.60 \\
\hline 2 & $\begin{array}{l}\text { The best time to start } \\
\text { planning investment is as } \\
\text { early as possible in the } \\
\text { workplace. }\end{array}$ & $1 \%$ & $23 \%$ & $44 \%$ & $32 \%$ & $100 \%$ & 3.07 \\
\hline 3 & $\begin{array}{l}\text { The best time to start } \\
\text { planning investment is in } \\
\text { the middle of a job. }\end{array}$ & $14 \%$ & $39 \%$ & $42 \%$ & $5 \%$ & $100 \%$ & 2.39 \\
\hline
\end{tabular}

In table 4 below shows the type of investment option. There are several possibilities of women workers in choosing investment types such as stocks, mutual funds, bonds; insurance; savings, deposits; gold; property; and other investments. The result shows that the majority of the respondents feel more interested in this type of property investment. The results can be seen from the fourth statement that the average of the score is greater than the other, which are 3.41. The second most popular type of investment is an investment in the form of savings and deposits. Based on these results, it indicates that the respondent is a risk-averse investor type (risk avoiding). The results are inseparable from the culture of employees in the minds of women workers, so the majority does not dare to take risks as usually done by the respondent who has an entrepreneurship background.

Table 4: Types of Investment

\begin{tabular}{|c|c|c|c|c|c|c|c|}
\hline No & Statement & $\begin{array}{l}\text { Score } \\
1 \text { (STS) } \\
\end{array}$ & 2(TS) & $3(S)$ & $4(S S)$ & Total & Average \\
\hline 1 & $\begin{array}{l}\text { I prefer investments in the form } \\
\text { of stocks, mutual funds, bonds. }\end{array}$ & $23 \%$ & $45 \%$ & $27 \%$ & $4 \%$ & $100 \%$ & 2.12 \\
\hline 2 & I prefer investing in insurance. & $22 \%$ & $37 \%$ & $30 \%$ & $11 \%$ & $100 \%$ & 2.30 \\
\hline 3 & $\begin{array}{l}\text { I prefer investing in savings, } \\
\text { deposits. }\end{array}$ & $5 \%$ & $7 \%$ & $42 \%$ & $46 \%$ & $100 \%$ & 3.29 \\
\hline 4 & $\begin{array}{l}\text { I prefer investing in gold. } \\
\text { I prefer investing in the form of }\end{array}$ & $3 \%$ & $13 \%$ & $47 \%$ & $37 \%$ & $100 \%$ & 3.19 \\
\hline 5 & land, buildings (property). & $1 \%$ & $7 \%$ & $41 \%$ & $51 \%$ & $100 \%$ & 3.41 \\
\hline 6 & $\begin{array}{l}\text { I prefer investment in other } \\
\text { forms. }\end{array}$ & $27 \%$ & $31 \%$ & $28 \%$ & $13 \%$ & $100 \%$ & 2.28 \\
\hline
\end{tabular}


Table 5: Reasons to Invest

\begin{tabular}{|c|c|c|c|c|c|c|c|}
\hline No & Statement & $\begin{array}{l}\text { Score } \\
1 \text { (STS) } \\
\end{array}$ & $2(\mathrm{TS})$ & $3(S)$ & $4(S S)$ & Total & Average \\
\hline 1 & $\begin{array}{l}\text { I invest because I want high } \\
\text { returns. }\end{array}$ & $3 \%$ & $15 \%$ & $45 \%$ & $37 \%$ & $100 \%$ & 3.16 \\
\hline 2 & $\begin{array}{l}\text { I invest because I want the } \\
\text { benefits/tax advantages. }\end{array}$ & $12 \%$ & $39 \%$ & $39 \%$ & $11 \%$ & $100 \%$ & 2.48 \\
\hline 3 & $\begin{array}{l}\text { I invest because there is an } \\
\text { emergency need/vigilance } \\
\text { motive }\end{array}$ & $7 \%$ & $21 \%$ & $45 \%$ & $28 \%$ & $100 \%$ & 2.93 \\
\hline 4 & $\begin{array}{l}\text { I invest due to retirement } \\
\text { plans. }\end{array}$ & $1 \%$ & $4 \%$ & $41 \%$ & $54 \%$ & $100 \%$ & 3.47 \\
\hline 5 & I invest for family security. & $1 \%$ & $4 \%$ & $43 \%$ & $52 \%$ & $100 \%$ & 3.45 \\
\hline 6 & $\begin{array}{l}\text { I invest in children's } \\
\text { education. }\end{array}$ & $3 \%$ & $7 \%$ & $36 \%$ & $55 \%$ & $100 \%$ & 3.43 \\
\hline 7 & $\begin{array}{l}\text { I invest to use it in the } \\
\text { future. }\end{array}$ & $8 \%$ & $24 \%$ & $51 \%$ & $17 \%$ & $100 \%$ & 2.77 \\
\hline 8 & I invest for other reasons: & $28 \%$ & $35 \%$ & $25 \%$ & $12 \%$ & $100 \%$ & 2.21 \\
\hline
\end{tabular}

In table 5 above shows the reasons for women workers in doing an investment. The result shows that the majority of respondents are investing due to pension plans. The results can be seen from the fourth statement that the average of the score is greater than the other, which are 3.47. The results are not separated from the culture of the employees and the majority of respondents are working in government then the idea of retirement becomes the reason to do an investment. Also, the second reason for women workers to invest is family safety. The results can be seen from the fifth statement that the average of the score is greater than the other, which are 3.45. The first and second greatest answers have a high correlation, if it is concluded then the reason for the respondent to invest is to keep the family safe with the preparation of the pension program.

Table 6: Investment Supporting Subject

\begin{tabular}{llllllll}
\hline No & Statement & $\begin{array}{l}\text { Score } \\
\mathbf{1}(\mathbf{S T S})\end{array}$ & $\mathbf{2 ( T S )}$ & $\mathbf{3 ( S )}$ & $\mathbf{4 ( S S )}$ & Total & Average \\
\hline 1 & Oneself & $3 \%$ & $7 \%$ & $47 \%$ & $43 \%$ & $100 \%$ & 3.32 \\
2 & Husband & $18 \%$ & $14 \%$ & $41 \%$ & $27 \%$ & $100 \%$ & 2.76 \\
3 & Siblings/ Close family & $18 \%$ & $31 \%$ & $40 \%$ & $11 \%$ & $100 \%$ & 2.44 \\
4 & Parents & $12 \%$ & $18 \%$ & $45 \%$ & $25 \%$ & $100 \%$ & 2.82 \\
5 & Friends/ Peers & $16 \%$ & $31 \%$ & $49 \%$ & $4 \%$ & $100 \%$ & 2.41 \\
6 & Investment Company & $25 \%$ & $43 \%$ & $28 \%$ & $4 \%$ & $100 \%$ & 2.12 \\
7 & Others & $38 \%$ & $36 \%$ & $22 \%$ & $4 \%$ & $100 \%$ & 1.93 \\
\hline
\end{tabular}

Table 6 above shows that what drives women workers to invest is themselves. The results can be seen from the first criterion that the average score is greater than the other, which are 3.32. Besides them themselves that become the reason to invest, respondents also feel that parents also encourage the occurrence of investments made by respondents. 
Table 7: Aspects of Investment Planning

\begin{tabular}{|c|c|c|c|c|c|c|c|}
\hline No & Statement & $\begin{array}{l}\text { Score } \\
1 \text { (STS) } \\
\end{array}$ & $2(\mathrm{TS})$ & $3(S)$ & $4(S S)$ & Total & Average \\
\hline 1 & $\begin{array}{l}\text { I am disciplined in } \\
\text { saving / investing }\end{array}$ & $1 \%$ & $17 \%$ & $66 \%$ & $16 \%$ & $100 \%$ & 2.96 \\
\hline 2 & $\begin{array}{l}\text { I have control over my } \\
\text { finances }\end{array}$ & $1 \%$ & $4 \%$ & $59 \%$ & $36 \%$ & $100 \%$ & 3.29 \\
\hline 3 & $\begin{array}{l}\text { I enjoy doing } \\
\text { investment planning }\end{array}$ & $0 \%$ & $1 \%$ & $70 \%$ & $29 \%$ & $100 \%$ & 3.27 \\
\hline 4 & $\begin{array}{l}\text { I often invest money } \\
\text { when I do not plan to } \\
\text { buy anything }\end{array}$ & $3 \%$ & $20 \%$ & $46 \%$ & $32 \%$ & $100 \%$ & 3.07 \\
\hline 5 & $\begin{array}{l}\text { I think preparing for } \\
\text { investment takes a lot } \\
\text { of time and effort }\end{array}$ & $8 \%$ & $30 \%$ & $45 \%$ & $17 \%$ & $100 \%$ & 2.71 \\
\hline 6 & $\begin{array}{l}\text { I think everyone can get } \\
\text { a profitable investment } \\
\text { if they do planning and } \\
\text { saving/investing }\end{array}$ & $0 \%$ & $7 \%$ & $51 \%$ & $43 \%$ & $100 \%$ & 3.36 \\
\hline 7 & $\begin{array}{l}\text { I am willing to take } \\
\text { risks to make a profit }\end{array}$ & $7 \%$ & $34 \%$ & $50 \%$ & $9 \%$ & $100 \%$ & 2.62 \\
\hline 8 & $\begin{array}{l}\text { I'm more thrifty than an } \\
\text { investor }\end{array}$ & $8 \%$ & $50 \%$ & $39 \%$ & $3 \%$ & $100 \%$ & 2.37 \\
\hline 9 & $\begin{array}{l}\text { I do not want to take } \\
\text { the financial risk } \\
\text { whatever the result is }\end{array}$ & $9 \%$ & $42 \%$ & $41 \%$ & $8 \%$ & $100 \%$ & 2.47 \\
\hline
\end{tabular}

Table 7 above shows the aspects of investment planning. Based on the results of the study, it showed that women workers have good financial literacy. This discipline is also supported by investing the excess money if they do not have a plan to buy an item. These planning and disciplinary actions are due to these women workers having control over their finances (3.29). The generated income is indeed used to support family finances but they are not as the breadwinner for their family. Good financial literacy is also demonstrated by the full support (3.36) of investment planning because, to gain investment benefits planning should be done.

\section{Conclusion}

The majority of respondents of women workers have married with the average age of 16-22 years and with Bachelor as the majority education background, and work in the government sector with majority revenues ranged above $\mathrm{Rp} \mathrm{4,000.000,-.} \mathrm{The} \mathrm{respondent's} \mathrm{characteristic} \mathrm{will} \mathrm{influence} \mathrm{the} \mathrm{choice} \mathrm{of} \mathrm{investment} \mathrm{because}$ it is related to its tolerance for risk. The first form of investment behavior and preference of women workers is that the majority of women workers have thought of an investment plan. Although the investment plan is still in their mind and has not been further developed, the thinking phase of the investment plan occurs in the initial time of joining an organization or company. The second form of investment behavior and preference of women workers is that the majority of respondents feel more interested in the type of property investment. The second most popular type of investment is an investment in the form of savings and deposits. The 
majority of respondents feel that everyone can get a profitable investment if they do planning and saving/investing. Based on the result, it indicates that the respondent is a risk-averse investor type (risk avoiding). The result was supported by the fact that the type of investor that existed in women workers was short-term investors, so the majority of respondents prefer a period of one-month investments. This is in line with the research (Yuh \& Hanna, 1996; Sung, 1997; Bajtelsmit \& VanDerhei, 1997; Selvi, 2012, Bahl, 2012, Indrawan, 2014 and Retno, 2014).

Which states that women do not like risk and invest a greater proportion from their portfolios at low risk, lower assets, in this case, are real assets. The third form of investment behavior and preference of the women workers is that the thing encourages women workers to invest is she for the sake of retirement plans and family security reasons. Based on the results of the study, it showed that women workers have high financial literacy. It is indicated by the discipline of investing the excess money, to have control over their finances and have the confidence to earn investment profits, and they must perform financial planning. Considering that this study has a limitation, the suggestion given in generalizing the result is that prudential principles need to be implemented. First, the number of respondents is relatively limited; second, demographic factors used in this study were limited to age, marital status, education, occupation, and income. In Indonesia, investment behavior is also influenced by other factors, such as tribe and religion. Third, this study only focuses on demographic factors and does not include psychological factors. Investment choices and tolerance to risk are also influenced by psychological factors. The result of this study will benefit banking and Investment Company. Banking and Investment Company need to understand the demographical factor of its customers to compile investment products, which is suitable for customers' characteristics.

\section{References}

Ajzen, I. (1985). From Intentions to Action: Theory of Planned Behavior. New York: Springer.

Ajzen, I. (1991). Theory of planned behavior. Journal Organizational Behavior and Human Decision Processes, $50,179-211$.

Ajzen, I. \& Fishbein, M. (1977). Attitude-Behavior Relations: A Theoretical Analysis and Review of Empirical Research. Psychological Bulletin, 84(5), 888-918.

Ajzen, I. \& Fishbein, M. (2000). Attitudes and the Attitude-Behavior Relation: Reasoned and Automatic Processes. European Review of Social Psychology, 11(1), 1-33.

Allport, G. W. (1954). The Nature of Prejudice. Oxford: Addison-Wesley.

Azwar, S. (2000). Sikap Manusia, Teori, dan Pengukurannya. Jogjakarta: Pustaka Pelajar Jogja Offset.

Bahl, S. (2012). Investment Behaviour of Working Women of Punjab. A Journal of Economics and Management, $1(6)$.

Bajtelsmit, V. L. \& VanDerhei, J. L. (1997). Risk Aversion and Pension Investment Choices. Positioning Pensions for the Twenty-First Century (Vol. 35). Philadelphia: University of Pennsylvania Press.

Baker, H. K. \& Nofsinger, J. R. (2010). Behavioral Finance: Investors, Corporations, and Markets. New Jersey: John Wiley \& Sons.

Bernasek, A. \& Shwiff, S. A. (2001). Gender, Risk, and Retirement. Journal of Economic Issues, 35(2), 345-356.

Butler, K. C. \& Domian, D. L. (1991). Risk, Diversification, and the Investment Horizon. The Journal of Portofolio Management, 17(3), 41-48.

Byrnes, J. P., Miller, D. C. \& Schafer, W. D. (1999). Gender Differences in Risk Taking: A Meta-Analysis. Psychological Bulletin, 125(3), 367-383.

Chang, R. Y. (1998). Langkah-langkah Pemecahan Masalah. Jakarta: PT Pustaka Binaman Pressindo.

Chen, H. \& Volpe, R. P. (1998). An Analysis of Personal Financial Literacy Among College Students. Financial Services Review, 7(2), 107-128.

Christanti, N. \& Mahastanti, L. A. (2011). Faktor-faktor yang Dipertimbangkan Investor dalam Melakukan Investasi. Jurnal Manajemen Teori Dan Terapan, 4(3), 37-51.

Dharmmesta, B. S. (1998). Theory Of Planned Behavior dalam Penelitian Sikap, Niat dan Perilaku Konsumen. Kelola, 8(7), 85-163.

Eckel, C. C. \& Grossman, P. J. (2002). Differences in the Economic Decisions of Men and Women: Experimental Evidence. North-Holland, Amsterdam, The Netherlands: Elsevier Science B. V.

Gneezy, U., Leonard, K. L. \& List, J. A. (2009). Gender Differences in Competition: Evidence from a Matrilineal and a Patriarchal Society. Econometrica, 77(5), 1637-1664. 
Hartono, J. (2003). Teori Portofolio dan Analisis Investasi. Yogyakarta: BPFE-Yogyakarta.

Hibbert, A. M., Lawrence, E. \& Prakash, A. (2008). Are Woman More Risk-Averse Than Men?, 1-56.

Hidayat, R. (2010). Keputusan Investasi Dan Financial Constraints: Studi Empiris Pada Bursa Efek Indonesia. Buletin Ekonomi Moneter Dan Perbankan, 12(4), 457-479.

Hinz, R. P., McCarthy, D. D. \& Turner, J. A. (1997). Are WOmen Conservative Investors? Gender Differences in Participants-Directed Pension Investments. Philadelphia: University of Pennsylvania Press.

Indonesia, S. (2017). East Java Province in Figures.

Indrawan, H. (2014). Variabel Demografi Wanita Bekerja di Surabaya dalam Pemilihan Jenis Investasi Keluarga. FINESTA, 2(1), 71-75.

Jahanzeb, A., Muneer, S. \& Ur-Rehman, S. (2012). Implication of Behavioral Finance in Investment Decisionmaking Process. Information Management and Business Review, 4(10), 532-536.

Jain, R. (2014). An Analysis of Income and Investment Pattern of Working Women in the City of Ahmedabad. International Journal of Research in Management \& TechnologyInternational Journal of Research in Management \& Technology, 4(46), 139-146.

Jisha, V. G. \& GoMathi, V. (2017). A Study on the Perception of Investment Pattern among Urban Working Women with Reference to Coimbatore City. International Journal of Engineering Science and Computing, 7(2), 4303-4307.

Kreitner, R. \& Kinicki, A. (2001). Organizational Behavior. Irwin McGraw-Hill.

Mincer, J. \& Polachek, S. (1974). Family Investments in Human Capital: Earnings of Women Family Investments in Human Capital: Earnings of Women. Journal Pf Political Economy, 82(2), 76-108.

Mittal, M. (2010). Study of Differences in Behavioral Biases in Investment Decision Making. The IUP Journal of Behavioral Finance, 7(4), 20-34.

Mowen. (1995). Perilaku Konsumen dan Komunikasi Pemasaran. Jakarta: Karangan Sutisna.

Notoatmodjo, S. (1997). Pengembangan Sumber Data Manusia. Jakarta: Penerbit PT Rineka Cipta.

Olsen, R. A. \& Cox, C. M. (2001). The Influence of Gender on the Perception and Response to Investment Risk: The Case of Professional Investors. Journal of Psychology and Financial Markets, 2(1), 29-36.

Peteros, R. \& Maleyeff, J. (2013). Application of Behavioral Finance Concept to Investment Decision Making: Suggestion for Improving Investment Education Courses. International Journal of Management, 30(1), 249-261.

Purwanto, H. (1998). Pengantar Perilaku Manusia untuk Keperawatan. Jakarta: EGC.

Rahadjeng, E. R. (2011). Analisis Perilaku Investor Perspektif Gender dalam Pengambilan Keputusan Investasi di Pasar Modal. E-Journal Universitas Muhammadiyah Malang, 6, 90-97.

Rajarajan, V. (2000). Predictors of Expected Rate of Return by Individual Investors. The Indian Journal of Commerce, 53(4), 65-70.

Retno, R. N. H. (2014). Analisis Keputusan Investasi oleh Tenaga Kerja Indonesia. Jurnal Ilmiah Mahasiswa FEB Universitas Brawijaya, 2, 2.

Selvi, T. T. (2012). A Study on Investment Behaviour of Women Entrepreneurs in Coimbatore District. Unpublished Dissertation, Mother Teresa Women's University India.

Shefrin, H. (2000). Beyond Greed and Fear: Understanding Behavioral Finance and Psychology of Investing. Boston: Harvard Business School Press.

Sunariyah. (2003). Pengantar Pengetahuan Pasar Modal. Yogyakarta: (UPP) AMP YKPN.

Sunden, A. E. \& Surette, B. J. (1998). Gender Differences in the Allocation of Assets in retirement Savings Plans. American Economic Review, 88(2), 207-211.

Sung, J. (1997). A Structural Analysis of Retirement Funds in a Family Context: Participation and Investment in Stocks. Unpunlished Dissertations, the Ohio State University , Columbus, $\mathrm{OH}$.

Tandelilin, E. (2010). Portofolio dan Investasi: Teori dan Aplikasi. Yogyakarta: Kanisius.

Warren, W. E., Stevens, R. E. \& McConkey, C. W. (1990). Using Demography and Lifestyle Analysis to Segment Individual Indualestors: A Segmentation Approach. Journal of Behavioral Finance, 5(3), 170-179.

Yuh, Y. \& Hanna, S. D. (1997). The Demand for Risky Assets in Retirement Portfolios. Proceedings of the Academy Financial Services, (July), 1-10. 